\title{
ALKALOIDS FROM OXYTROPIS MYRIOPHYLLA (PALL) DC
}

Keisuke Kojima $(+)^{1}$, Purevsuren $S^{2}{ }^{2}$, Narantuya $S^{3}{ }^{*}$, Tsetsegmaa $S .{ }^{2}$, Jamyansan Ya. ${ }^{3}$, Kimio Isaka ${ }^{1}$, Yukio Ogihara ${ }^{1}$

${ }^{1}$ Faculty of Pharmaceutical Sciences, Nagoya City University, 3-1 Tanabe Dori, Mizuhoku, Nagoya 467, Japan

${ }^{2}$ Depart. of Pharmacy, Mongolian Medical University, Ulaanbaatar-3, Mongolia

${ }^{3}$ Institute of Chemistry and Chemical Technology, Mongolian Academy of Sciences, Ulaanbaatar-51, Mongolia

For the memory of our colleague and friend Keisuke Kojima

\section{Summary}

Five alkaloids were isolated from the epigeal part of Oxytropis myriophylla. Three alkaloids were identified as $N$-benzoyl- $\beta$-phenylethylamine, $N$-trans-cinnamoyl- $\beta$-phenylethylamine, $\mathrm{N}$-cis-cinnamoyl- $\beta$-phenylethylamine and the structures of two new alkaloids were elucidated to be $\mathrm{N}$-benzoyl- $\beta$-hydroxyphenylethylamine (2), $\mathrm{N}$-trans-cinnamoyl- $\beta$-hydroxyphenylethylamine (5). The absolute structures were established by modified Mosher method.

\section{Keywords:}

Oxytropis myriophylla (Pall) DC, Fabaceae, alkaloid, N-benzoyl- $\beta$-phenylethylamine, $\mathrm{N}$ trans-cinnamoyl- $\beta$-phenylethylamine, $\mathrm{N}$-cis-cinnamoyl- $\beta$-phenylethylamine, $\mathrm{N}$-benzoyl- $\beta$ hydroxy-phenylethylamine, N-trans-cinnamoyl- $\beta$-hydroxyphenylethylamine.

\section{Introduction}

The Oxytropis genus is one of the most wide spread genus of the family Fabaceae and 81 Oxytropis species are growing in Mongolia [1]. Oxytropis species are widely used in Mongolian and Tibetan traditional medicines as diuretic, anti-septic, antifever, preventing from some infectious diseases [2].

$O$. myriophylla is the most popular component of many traditional prescriptions and named

as "stag-sha" in Mongolian traditional medicine. O.myriophylla is perennial herbaceous 
plants reaching $15-40 \mathrm{~cm}$ in height and distributed in forested high mountainous part of Mongolia. O. myriophylla has been reported to contain flavonoids (kaempferol and quercetin derivatives [3]) and alkaloids.

The present study showed that $O$. myriophylla contained five alkaloid constituents. The dried epigeal parts collected in Mongolia were extracted with EtOH. From the extract, Nbenzoyl- $\beta$-phenylethylamine (1) [4], N-benzoyl- $\beta$-hydroxyphenylethylamine (2) $[4,5], \mathrm{N}$ trans-cinnamoyl- $\beta$-phenylethylamine (3) [5], N-cis-cinnamoyl- $\beta$-phenylethylamine (4), Ntrans-cinnamoyl- $\beta$-hydroxy phenylethylamine (5) were obtained.

Compound 4, which has cis-cinnamoyl group is very rare in nature, compounds $\mathbf{2}$ and $\mathbf{5}$ are the new alkaloids. The structure of alkaloids 1-5 have been elucidated as outlined below.

\section{Results and Discussion}

Compound 2 showed a $[\mathrm{M}+\mathrm{H}]^{+}$peak at $\mathrm{m} / \mathrm{z} 242$ corresponding to a molecular formula of $\mathrm{C}_{15} \mathrm{H}_{15} \mathrm{O}_{2} \mathrm{~N}$. The IR spectrum of 2 showed absorption bands for aromatic bond $\left(1640 \mathrm{~cm}^{-1}\right)$. The ${ }^{1} \mathrm{H}$ and ${ }^{13} \mathrm{C}$ NMR spectra of 2 revealed the presence of one benzoyl group which bound to $\beta$-hydroxyphenylethylamine, confirmed by the two mono-substituted benzen ring and an amidic $\mathrm{CO}\left(\delta_{\mathrm{c}}\right.$ 170.6) and a hydroxymethin $\left(\delta_{\mathrm{H}} 4.90, \delta_{\mathrm{c}} 73.6\right)$ coupled with methylene $\left(\delta_{\mathrm{H}}\right.$ $\left.3.54,3.64, \delta_{c} 48.3\right)$. The confirmation of the structure was possible by application of the HMBC. Therefore, the structure of 2 was elucidated to be N-benzoyl- $\beta$ hydroxyphenylethylamine.

Compound 1 was also confirmed as N-benzoyl- $\beta$-phenylethylamine by NMR. 1 and 2 have been isolated from O.trichophysa [4]. But, absolute structure of 2 have not been elucidated. In order to determine the absolute configuration of 2 at the C-7 position, we applied the modified Mosher method to this compound [6]. Two diastereomers were prepared from 2 by the treatment with $(+)$ and (-)-MTPA chloride in the presence of DMAP. The $\Delta_{\delta}$ values, which were calculated by the measurement of ${ }^{\prime} \mathrm{H}$ NMR, are shown Fig.1. Thus, it was determined that 2 was $(7 S)$. 
Compound 3 and 4 gave rise to ${ }^{1} \mathrm{H}$ and ${ }^{13} \mathrm{C}$ NMR spectra that were similar to those of 1 , except for the presence of trans olefin at $\delta_{\mathrm{H}} 6.57,7.52(\mathrm{~J}=16 \mathrm{~Hz})$ as trans-cinnamoyl group at 3 , and cis olefin at $\delta_{\mathrm{H}} 5.98,6.73(\mathrm{~J}=13 \mathrm{~Hz})$ as cis-cinnamoyl group at 4 . On the basis of NMR including HMBC, 3 and 4 were assigned N-trans-cinnamoyl- $\beta$-phenylethylamine and $\mathrm{N}$-cis-cinnamoyl- $\beta$-phenylethylamine respectively.<smiles>O=C(NCCc1ccccc1)c1ccccc1</smiles>

1<smiles>O=C(/C=C/c1ccccc1)NCCc1ccccc1</smiles>
2<smiles>O=C(/C=C/c1ccccc1)NCC(O)c1ccccc1</smiles>

5<smiles>O=C(NCC(O)c1ccccc1)c1ccccc1</smiles><smiles>O=C(/C=C\c1ccccc1)NCCc1ccccc1</smiles>

4 
Compound 5 showed a $[\mathrm{M}+\mathrm{H}]^{+}$peak at $\mathrm{m} / \mathrm{z} 269$ corresponding to a molecular formula of $\mathrm{C}_{17} \mathrm{H}_{17} \mathrm{O}_{2} \mathrm{~N}$. The ${ }^{1} \mathrm{H}$ and ${ }^{13} \mathrm{C}$ NMR spectra of 5 also revealed the presence of one transcinnamoyl group which bound $\beta$-hydroxyphenylethylamine. Thus, it was elucidated to be $N$ trans- cinnamoyl- $\beta$-hydroxyphenylethylamine. The absolute configuration was assumed to be (7S) by optical rotation compared with 2 .

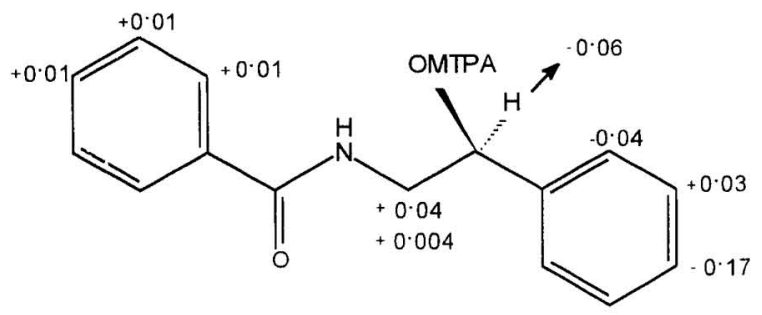

Fig. 1

This type of alkaloids, $N$ - cinnamoyl- $\beta$-phenylethylamine analogues, were reported as the inhibitors of prostaglandin biosynthesis [7-9].

\section{Experimental}

General. NMR spectra were recorded on a $J E O L J N M-A 500$ spectrometer with $T M S$ as int. standard. FAB-MS were recorded on a $J E O L J M S-D X 300$ spectrometer. Optical rotation were measured with a JASCO DIP-4 digital polarimeter. IR spectra were recorded on a SHIMADZU FTIR-8100 spectrometer.

Plant material. The epigeal parts of Oxytropis myriophylla (Pall) DC was collected in surrounding of Ulaanbaatar city, Mongolia, during the full flowering period at the end of July 1995. It is identified by Dr.E.Ganbold, Institute of Biology, Mongolian Academy of Sciences. A voucher specimen of the plant deposited in the Herbarium of the Institute of Biology, Mongolian Academy of Sciences (UBA).

Extraction and isolation. The air-dried epigeal part of O.myriophylla were extracted with 
EtOH and concentrated to give an concentrated EtOH extract. The EtOH extract was dissolved in water, which was extracted with hexane, chloroform, ethyl acetate, and $n$ butanol successively. The chloroform extract was subjected to Silica gel column chromatography with a solvent mixture of hexane and ethyl acetate (9:1-1:9). Four fractions (I-IV) were collected according to TLC analysis. Fraction I was rechromatographed on Silica gel with a solvent mixture of hexane and ethyl acetate in stepwise manner to give $\mathbf{2}$ $(17 \mathrm{mg}), 5(5 \mathrm{mg})$. Fraction II was rechromatographed on Silica gel with a solvent mixture of hexane and ethyl acetate in stepwise manner to give benzoic acid $(10 \mathrm{mg})$. Fraction III was rechromatographed on Lober ODS with a $50 \% \mathrm{CH}_{3} \mathrm{CN}$ to give $1(20 \mathrm{mg}), 3(6 \mathrm{mg})$ and 4 ( $2 \mathrm{mg}$ ). Fraction IV was rechromatographed on Silica gel with a solvent mixture of chloroform and $\mathrm{MeOH}$ in stepwise manner to give pinitol (5 mg).

N-benzoyl- $\beta$-hydroxyphenylethylamine (2). $[\alpha]_{D}{ }^{17}-4.27^{0}(\mathrm{MeOH} ; \mathrm{c} 1.0)$. FAB-MS $m / z$ : $242[\mathrm{M}+\mathrm{H}]^{+}, 240[\mathrm{M}-\mathrm{H}], 264[\mathrm{M}+\mathrm{Na}]^{+}$. IR $\lambda_{\max }\left(\mathrm{CHCl}_{3}\right): 1640 \mathrm{~cm}^{-1}$

${ }^{1} \mathrm{H}$ NMR $\left(\mathrm{CD}_{3} \mathrm{OD}\right): 7.42(1 \mathrm{H}, \mathrm{br} \mathrm{d}, \mathrm{J}=7 \mathrm{~Hz}, \mathrm{H}-2), 7.35(1 \mathrm{H}, \mathrm{br} \mathrm{t}, \mathrm{J}=7 \mathrm{~Hz}, \mathrm{H}-3), 7.27(1 \mathrm{H}$, br t, $\mathrm{J}=7 \mathrm{~Hz}, \mathrm{H}-4), 7.35(1 \mathrm{H}$, br t, J=7, H-5), $7.42(1 \mathrm{H}, \mathrm{br} \mathrm{d}, \mathrm{J}=7 \mathrm{~Hz}, \mathrm{H}-6), 4.90(1 \mathrm{H}, \mathrm{dd}, \mathrm{J}=5.8 \mathrm{~Hz}$, $\mathrm{H}-7), 3.64(1 \mathrm{H}, \mathrm{dd}, \mathrm{J}=5.14 \mathrm{~Hz}, \mathrm{H}-8 \mathrm{a}), 7.78\left(1 \mathrm{H}, \mathrm{br} \mathrm{d}, \mathrm{J}=8 \mathrm{~Hz}, \mathrm{H}-2^{\prime}\right), 7.44(1 \mathrm{H}, \mathrm{br} \mathrm{t}, \mathrm{J}=8 \mathrm{~Hz}$, H-3'), $7.52\left(1 \mathrm{H}\right.$, br $\left.t, J=8 \mathrm{~Hz}, \mathrm{H}-4^{\prime}\right), 7.44\left(1 \mathrm{H}, \mathrm{br} \mathrm{t}, \mathrm{J}=8 \mathrm{~Hz}, \mathrm{H}-5^{\prime}\right) 7.78(1 \mathrm{H}, \mathrm{br} \mathrm{d}, \mathrm{J}=8 \mathrm{~Hz}$, H-6').

${ }^{13} \mathrm{C}$ NMR (CD $\left.{ }_{3} \mathrm{OD}\right): 144.0$ (C-1), 127.3 (C-2), 129.4 (C-3), 128.7 (C-4), 129.4 (C-5), 127.3 (C-6), 73.6 (C-7), 48.3 (C-8), 135.7 (C-1'), 128.3 (C-2'), 129.6 (C-3'), 132.7 (C-4'), 129.6 $\left(\mathrm{C}-5^{\prime}\right), 128.3\left(\mathrm{C}-6^{\prime}\right), 170.6\left(\mathrm{C}-7^{\prime}\right)$

$\mathrm{N}$-trans- cinnamoyl- $\beta$-hydroxyphenylethylamine (5). $[\alpha]_{\mathrm{D}}{ }^{18}-9.66^{\circ}(\mathrm{MeOH} ; \mathrm{c} \quad \mathrm{I} .0)$. FAB-MS $m / z: 269[\mathrm{M}+\mathrm{H}]^{+}, 267[\mathrm{M}-\mathrm{H}], 291[\mathrm{M}+\mathrm{Na}]^{+}$

${ }^{1} \mathrm{H}$ NMR $\left(\mathrm{CD}_{3} \mathrm{OD}\right): 7.41(1 \mathrm{H}$, br d, J=7Hz, H-2), $7.35(1 \mathrm{H}$, br t $, \mathrm{J}=7 \mathrm{~Hz}, \mathrm{H}-3), 7.27(1 \mathrm{H}$, br t, $\mathrm{J}=7 \mathrm{~Hz}, \mathrm{H}-4), 7.35(1 \mathrm{H}$, br $\mathrm{t}, \mathrm{J}=7, \mathrm{H}-5), 7.41(1 \mathrm{H}, \mathrm{br} \mathrm{d}, \mathrm{J}=7 \mathrm{~Hz}, \mathrm{H}-6), 4.82(1 \mathrm{H}, \mathrm{dd}$, $\mathrm{J}=5.8 \mathrm{~Hz}, \mathrm{H}-7), 3.59(1 \mathrm{H}, \mathrm{dd}, \mathrm{J}=5.14 \mathrm{~Hz}, \mathrm{H}-8 \mathrm{a}), 3.44(1 \mathrm{H}, \mathrm{dd}, \mathrm{J}=8.14 \mathrm{~Hz}, \mathrm{H}-8 \mathrm{~b}) 7.55(1 \mathrm{H}, \mathrm{br}$ d, J=7Hz, H-2'), $7.38(1 \mathrm{H}$, br t, J=7Hz, H-3'), 7.37 (1H, br t, J=7Hz, H-4'), 7.38 (1H,br t, $\left.\mathrm{J}=7 \mathrm{~Hz}, \mathrm{H}-5^{\prime}\right) 7.55(1 \mathrm{H}$, br d, J=8Hz, H-6' $), 6.64\left(1 \mathrm{H}, \mathrm{d}, \mathrm{J}=16 \mathrm{~Hz}, \mathrm{H}-8^{\prime}\right), 7.53(1 \mathrm{H}, \mathrm{d}$, 
$\left.\mathrm{J}=16 \mathrm{~Hz}, \mathrm{H}-9^{\prime}\right)$.

${ }^{13} \mathrm{C}$ NMR (CD $\mathrm{OD}$ ): 144.0 (C-1), 127.2 (C-2), 129.4 (C-3), 128.7 (C-4), 129.4 (C-5), 127.2

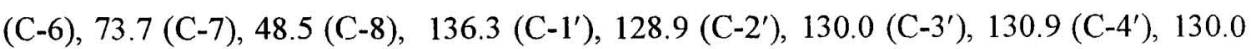
$\left(\mathrm{C}-5^{\prime}\right), 128.9\left(\mathrm{C}-6^{\prime}\right), 169.0\left(\mathrm{C}-7^{\prime}\right), 121.8\left(\mathrm{C}-8^{\prime}\right), 141.9\left(\mathrm{C}-9^{\prime}\right)$,

$(+)$ - and (-) - MTPA ester of 2. (+)-MTPA chloride (10 $\mu \mathrm{l})$ and DMAP (5 mg) was added to a solution of $2(7 \mathrm{mg})$ in $\mathrm{CH}_{2} \mathrm{Cl}_{2}$ at room temperature. The mixture was stirred for $3 \mathrm{~h}$ and then the mixture was applied to column chromatography and purified to give $(+)-$ MTPA ester of 2 . The (-) -MTPA ester of $\mathbf{2}$ was prepared in a similar manner by the treatment with $(-)$ - MTPA chloride.

(-)-MTPA ester of 2: 'H- NMR $\delta: 7.32(\mathrm{H}-2,6), 7.21(\mathrm{H}-3,5), 7.31(\mathrm{H}-4), 3.88(\mathrm{H}-8 \mathrm{a})$, $3.66(\mathrm{H}-8 \mathrm{~b}), 7.79\left(\mathrm{H}-2^{\prime}, 6^{\prime}\right), 7.46\left(\mathrm{H}-3^{\prime}, 5^{\prime}\right), 7.56\left(\mathrm{H}-4^{\prime}\right)$

(+)-MTPA ester of 2: ${ }^{1} \mathrm{H}-\mathrm{NMR}$ 8: $7.36(\mathrm{H}-2,6), 7.18(\mathrm{H}-3,5), 7.48(\mathrm{H}-4), 3.84(\mathrm{H}-8 \mathrm{a})$, $3.65(\mathrm{H}-8 \mathrm{~b}), 7.68\left(\mathrm{H}-2^{\prime}, 6^{\prime}\right), 7.45\left(\mathrm{H}-3^{\prime}, 5^{\prime}\right), 7.55\left(\mathrm{H}-4^{\prime}\right)$

\section{References:}

1. Ulziihutag N. (1979), Oxytropis species, Ulaanbaatar, p. 89-92,

2. Ligga U. (1997), Medicinal plants of Mongolian traditional medicine, Ulaanbaatar, p.20

3. Blinova K. F., Be Tkhi Tkhuan. (1976), Chem. Prir. Soedin. 99

4. Batsuren D., Tsetsegmaa S., Batbayar N., Dungerdorj D., Akhmedzhanova V. I., Milgrom Yu. M., Tashkes Ya. V., Ibragimov A. A. (1992), Chem. Prir. Soedin. 388

5. Huneck S., Connolly I. D., Khaidav T. (1986), Fitoterapia, 57: 423

6. Ohtani I., Kusumi T., Kashman Y., Kakisawa H. (1997), J. Am. Chem. Soc, 113: 4092

7. Tseng C.-F., Mikajiri A., Shibuya M., Goda, Y., Ebizuka Y., Padmawinata K., Sankawa U. (1986), Chem. Pharm. Bull, $34: 1380$

8. Goda Y., Shibuya M., Sankawa U. (1987), Chem. Pharm. Bull, 35: 2668

9. Tseng C.-F., Iwakami S., Mikajiri A., Shibuya M., Hanaoka F., Ebizuka Y., Padmawinata K., Sankawa U. (1992), Chem. Pharm. Bull, 40:396 